\title{
PERCEPTIONS IN PURCHASE OF BRANDED SNACKS IN SMALL CITIES OF INDIA
}

\author{
Ms. Afreen Nasabi \\ Doctoral Candidate, School of Management, Srinivas University, India \\ Dr Madhubrata Satpathy \\ Faculty, School of Economics, BJB Autonomous College, Bhubaneswar, India \\ Dr Kalpana Sahoo \\ Faculty, School of HRM, XIM University, Bhubaneswar, India
}

Col Prof Dr J Satpathy

School of Management, Srinivas University, India and MUA, Nairobi.

\begin{abstract}
Substituting for meals, to counter hunger pangs, ultimately leading to fluctuations in taste buds, snackification is the buzzword among youth of Indian in small cities. The purpose of this study is to understand customer's perception towards purchase of different type of snack and food items in small cities of India. Snacking in small cities is perceived differently than in many developed cities. Since the market coverage is huge, with taste parameters and heterogeneities holding fort, marketers need to know how are snacks perceived to be consumed, how often, in what quantity and why? Data from a choice experiment were undertaken from 150 respondents and statistical tools were used SPSS and MS Excel. Primary data consists of firsthand information so I create a questionnaire Google doc and share the link through the social medial platform and collected 150 responses. Secondary data is all collected from the internet, Articles, journals and Literature. The purpose of the study is to determine customer perception and purchase of snacks. Sample size selected for the study is 150 populations selected from various small cities in India. Research design is based on response oriented descriptive research. Convenience Sampling method it helps easily take opinion to the customers. Tools for data analysis and presentation include Percentage analysis, Graphs and SPSS. It is observed that there is scope for healthy snacks, branded chips and consumed snack to occupy a high demand - scale in small cities of India. The spending on snacks market has risen over the years considering the change in perception about purchase of branded snacks
\end{abstract}

Key Words: Perception, Customer Economic behaviour, Branded Snacks and Snacks Market 
"For we all agree that the most excellent man should rule, i.e., the supreme by nature, and that the law rules and alone is authoritative; but the law is a kind of intelligence, i.e. a discourse based on intelligence. And again, what standard do we have what criterion of good things that is more precise than the intelligent man? For

all that this man will choose, if the decision is based on his knowledge, are good things and their contraries are bad. And since everybody chooses most of all what conforms to their own proper dispositions (a just man choosing to live justly, a man with bravery to live bravely, likewise a self-controlled man to live with selfcontrol), it is clear that the intelligent man will choose most of all to be intelligent; for this is the function of that capacity. Hence it's evident that, according to the most authoritative decision, intelligence is supreme among goods." .... Aristotle (in 'Protrepticus')

\section{Introduction}

Snacking is as old as civilization where hominids were munching what came their way as edibles. This was in sheer consonance with Darwin's Survival of the Fittest model. "It is not the strongest of the species that survives, nor the most intelligent; it is the one most adaptable to change" opined Charles Darwin. "It is not the strongest or the most intelligent who will survive but those who can best manage change" opines Leon C. Megginson. Customers have been tearing apart between these two diametrically opposing quotes and have taken a middle path. The middle path being, I don't go long without eating. I never starve myself: I grab a healthy snack as opined by Vanessa Hudgens.

India snacks market is segmented into Extruded Snacks, Chips, Namkeen and Others. In terms of market value share, Namkeen has the highest market share compared to all other segments Extruded Snacks, Chips and Others. Indian snacking food industry is a promising and booming arm of FMCG category. This is primarily due to evolving customer consumption patterns. Customers are intentionally looking for snacks to indulge in, to satisfy a craving or to hold themselves up until their next meal. This is chiefly due to economic significance and sentimental dynamics of customers. With rise in busy lifestyles, millennially and Gen Y have adopted snacking attitudes and are making different snack choices based on health, convenience, brand and trust. The future development of snack food markets in India aspires to get a competitive edge and advantage by securing a better position in the snack food retail shelves. At present, in both organized and unorganized market, savoury or salty foods like Namkeen is the leading segment. The analysis of customer demand snack food markets in India is a principal pointer of neuroeconomics as it represents a near pictureperfect nuptial of theory and neuro-econometrics. 


\section{Snacks Growth}

The future of India Snacks Market can be judged from the fact that this industry is expected to grow with double digit CAGR during the time frame of 2018 to 2024. India snacks market is divided between organized players and unorganized market. At present unorganized market is dominating Indian snacks market. The revenue in snack food segment amounted to over $\$ 5000$ million in 2019 and was programmed to grow annually by $7.5 \%$ CAGR 2019-2023 (Anuvat Jangchud, 2019). The industry, on an average, has expanded at the rate of $15.6 \%$ over the last few years.

Snack has been redefined from chips and cookies to beverages. India's snack food market is growing at 25\% CAGR compounded annual growth rate. The snack food industry has expanded at the rate of $15.6 \%$ over the last few years. To reach over US $\$ 109$ Billion by the year 2025, Salted Snacks will bring in healthy gains adding significant momentum to global growth. (Snacks Buying behavior in a pack priced at Rs 5/- )

\section{Literature Scan}

The factors influencing customer economic behaviour towards Snack food products are customers perception and mindset towards the snacks. The impact of purchaser dispositions toward item quality, item worth, and brand inclination. Customer buying the product the nation quality and price, flavour, easy of availability different meanings and interpretations for different customers. The research is about main predictors factors quality, price, flavour, easy of availability which are main role of customer economic behaviour while buying food products. As the food product in market in India is becoming more important and competitive to the presence of Indian companies, customers are found to more quality concept, price, flavour, availability. However, customer's buying decision making is also factor to be influenced by the price and quality factor related with various aspects of the goods such as price, quality, taste, health issues, and nutritional, etc. customer's buying behavior is also found to be influenced by the demographic factors such as gender, age, income, occupation, education, marital status, type of family.

World is more cognizant about customers whenever they make a purchase decision (Abdourrahmane, 2014). Health and environment consciousness becomes the most important criteria in international customers' intention to purchase OTOP snacks food products. The relationship between subjective norms and attitudes is significant and positive. Customer attitude to snacks is principally impacted by quality attributes (Abdourrahmane, 2014). In this research health and environment consciousness did not significantly predict the purchase intention of OTOP snacks food products. A perception study about Snacks items that are sold in a handy economy pack at a price of RS 5 revealed that it is very good thought it has advantages like ease in carrying, and it fits in the small office bag, quantities in such packs, are sufficient for single serve and it automatically avoids further over-eating chances (kulkarni, 1791). India snack's brands are strategically deploying this pack of Rs/- 5 for 
acquiring an un-catered market resulting in expansion of their market base through sales of this pack. Customer acceptance for such pack is so evident that the snacks brands of MNC are dragged to follow this small pack route. The acceptance for Rs.5 /- pack when factors combined together was highly motivated by age group rather consumption with drink. The snack consumption in this pack of Rs.5/- need to be conducted by combining the set of psychological factors which may derive few new useful segments for the marketing professionals.

A pricing strategy implemented to promote low-fat snack choices through vending machines with three time periods baseline, low-price intervention, post intervention. smaller price reductions for low-fat items and simultaneous price increases for high-fat items could result in net revenue gains and a net profit for vendors. Pricing strategies may be most effective with groups that have less disposable income, such as lower socio-economic groups or adolescent populations (Peter Hannam, 1997). Environmental strategies may be useful in promoting low-fat eating patterns in the general population. Pricing strategies that make lowfat foods much less expensive are clearly effective in increasing choices of low-fat foods. Pricing strategies are effective in increasing sales of less popular foods. Without affecting overall sales volume, machines increased significantly when prices were lowered and in the absence of a concurrent nutrition education intervention. (Peter Hannam, 1997)

Formulations of snacks significantly affected selected physicochemical characteristics and sensory liking, saltiness expectation, emotions and PI of these products (Anuvat Jangchud, 2019).The health benefit information on customers' saltiness expectation, sensory liking, elicited emotions and purchase intent of extruded snacks out of which flavour, saltiness, overall liking, bored, good and interested were critical attributes in differentiating snacks Product flavor, saltiness, emotions bored, good and interested were found to be critical perceptual factors explaining differences among extruded snack formulations. (Anuvat Jangchud, 2019). Some of the studies on innovative packaging attributes revealed that package is an essential part which is used to hold and preserve snacks, and facilitate the handling as well as products. Packaging design contains a lot of elements such as the thoughts and ideas of the products, the concepts of the brand, the type of food Purchase intention of Potato snacks is affected mainly by celebrity endorsement, re-usage value of the package and innovative features of the package (Gholamreza Zandi, 2019). The Re-usage value of the packaging can attract customers to buy products repeatedly Eco-friendliness is another packaging attribute that motivates customers to choose a particular brand. Innovative packaging features also can attract the customers to the purchase of potato snack food. The manufacturers, brands as well as organizations have to strategies more about how to improve the packaging design so that they can attract customers to buy their products. Some convenience features such as recyclability, one-hand use as well as portability that drive the innovation of food-packaging for processed food especially snacks (Gholamreza Zandi, 2019). The opening style of the package is attracted the customers mindset another key factor in snack food industry. When customers make the decision to purchase a product, they are concerned about the convenience characteristics such as handling, disposal, the visibility of 
the product, easy to access as well as opening style can have an influence on the package innovation.

Low price and Campaign to educate customer regarding customer right and Customer forum must be expedited. experience refers the attitudes towards the product formed by the directly consuming the product. the key drivers of demand for products are awareness/familiarity, perceived quality, sales quality and price. These tool drivers influence the perception of costumer in term of decision making. customer 's choice of food products is based on environmental issues as well as on issues concerning their health (Mr.Rajiv Vyas, 2016).

Majority of income level of average respondents is also average, because of all these reasons most of the respondents purchase non-branded product. The most joint families customers go for yearly storage of the food items taken up in the study and go for bulk purchasing whereas in nuclear families they prefer buying in small quantities as and when required. Large chunk of customers are aware about the branded packaged food items; this awareness is highest in the case of branded packaged wheat flour, followed by the packed rice, packed edible oil and least awareness in the case of branded sugar (Mr.Rajiv Vyas, 2016). Most of the respondents prefer to purchase these packaged food items from near grocery store or retail shop. Most of the respondents check the MRP mentioned on the pack before purchase and least of them check nutritional value mentioned on pack.

Most of the respondents are aware about customer right but they are not as much aware about customer forum. Most of the respondents never filed any case in customer court. Respondents who filed the case in customer court, most of them did not get any positive response. (Mr.Rajiv Vyas, 2016). Healthy snacks and contributes to a limited amount of existing literature by providing customer research for the development of new healthy snack foods. Focus groups are designed to explore customer attitudes and behaviors and are an excellent means in understanding the reasons why customers think, feel or act as they do. A healthy snack to be low in calories, fat, salt, and sugar and free from any artificial colours, sweeteners and flavours. Any snacks that contained whole-grain, fruit, oats, bran, nuts, seeds, raisins, pulses or flaxseed, were considered healthy. Taste appeared to be crucial in making decisions about snack food choice and was frequently mentioned as the primary reason for not choosing healthy snacks. For the most part, snack products labelled as "fat-free" or sugarfree. That taste was more important than healthiness and they were not willing to compromise on taste or flavours of snack food. Many of the barriers to healthy snack consumption found in this study mirrored customers' needs and wants in terms of new healthy snacks. Increasing the awareness of the importance of healthful eating patterns to enhance nutrition and health and reduce the risk of long-term illness. Customers factors driving healthy snack consumption among customers as a reduced risk of weight gain, diabetes, heart burn and bloating and the factors preventing healthy snack consumption as perceived taste, portion size, the lack of available convenient nutritional snacks, accessibility (Emily C, 2013). Majority of the male customers expected a healthy snack to contain low levels of calories, fat, salt and sugar, and to contain high levels of whole-grain, oats, bran, nuts, seeds, pulses and 
fruit. Major factors encouraging healthy snack consumption included reduced risk of weight gain, diabetes, heart burn and bloating. Customers expressed a desire for a wider choice of filling snacks with specific health benefits for a variety of usage occasions, particularly associated health claims such as high fibro. (Emily C, 2013)

The influence of marketing-controlled external motivators of impulse buying economic behaviour of snack foods in cafeterias among young customers is high. Most of customers prefer local store. Research done in this area has focused on the supermarket environment, neglecting other types of retail store. The marketing factors that influence the impulsive purchase of snack foods and use the findings to identify and characterize different segments of impulsive customers. Impulse buying is considered a constant and unique aspect of customers' lifestyle Buying is divided into planned and impulse purchases, depending on where the purchase decision is made. External motivators of impulsive buying are specific stimuli associated with marketing related variables and with shopping environment. There is a different buying orientation for snack foods among young customers brand orientation, communication orientation, product orientation, consumption environment orientation, price orientation, package orientation and sales interaction orientation. Customer Impulsive buying economic behaviour of snack foods using the eight factors revealed in the exploratory factor analysis. A new segment of health/nutrition-conscientious impulsive customers was uncovered and characterized. Impulse buying economic behaviour and that young customer can be effectively segmented in five groups. (Durate paulo, 2013)

Snacking behaviors have increased in parallel with obesity prevalence. The estimated marginal mean of the total aisle length of snack food items and the aisle length of individual snack food items was calculated adjusting for total store size across all countries. The shelf length of snack foods and the presence of these foods at checkouts and in end-of-aisle displays were assessed with noticeable variations detected between countries. UK supermarkets had the greatest aisle length devoted to chips, chocolate and confectionery, while soft drink aisle length was greatest in Australia. The proportion of both checkouts and end-of-aisle displays containing snack food was also highest in the Australian supermarkets. it is likely the role of supermarkets in supplying fresh fruit and vegetables to customers varies between nations based on the prominence and use of other retailers such as greengrocers or markets. It can be analysed majority of the snack food were founded in the super market. In this research data collection were collected from the different countries. It can be analysed that snack food items and aisle length of all individual snack food items were calculated adjusting for total store size across the all countries. (Adrim j Cameron, 2013)

\section{Research Methodology}

Primary Data: Primary data consists of firsthand information. A questionnaire on Google doc was designed and shared through the link via the social medial platform. Total of 150 responses were collected. 
Secondary Data: Secondary data were all collected from internet, Articles, journals and Literature. The purpose this was to oversee customer perception and purchase of snacks.

Sample design/size of sample: Sample size selected for the study is 150 populations selected from a cross - section of small cities in India.

Research Design: Exploratory Interpretive Research.

Sampling techniques: Under this method Convenience Sampling method has been used.

Tools for data analysis and presentation: Tools used for analysis of the data are Percentage analysis, Graphs and SPSS

\section{Objectives}

1) To study customer perception towards purchase of different type of snacks. Like chips, biscuits, chocolates, dry fruits, etc.

2) To understand perception of customers towards snacking habits.

\section{Data Analysis and Interpretation}

\section{Do you search for product information before purchase of a snacks packet?}

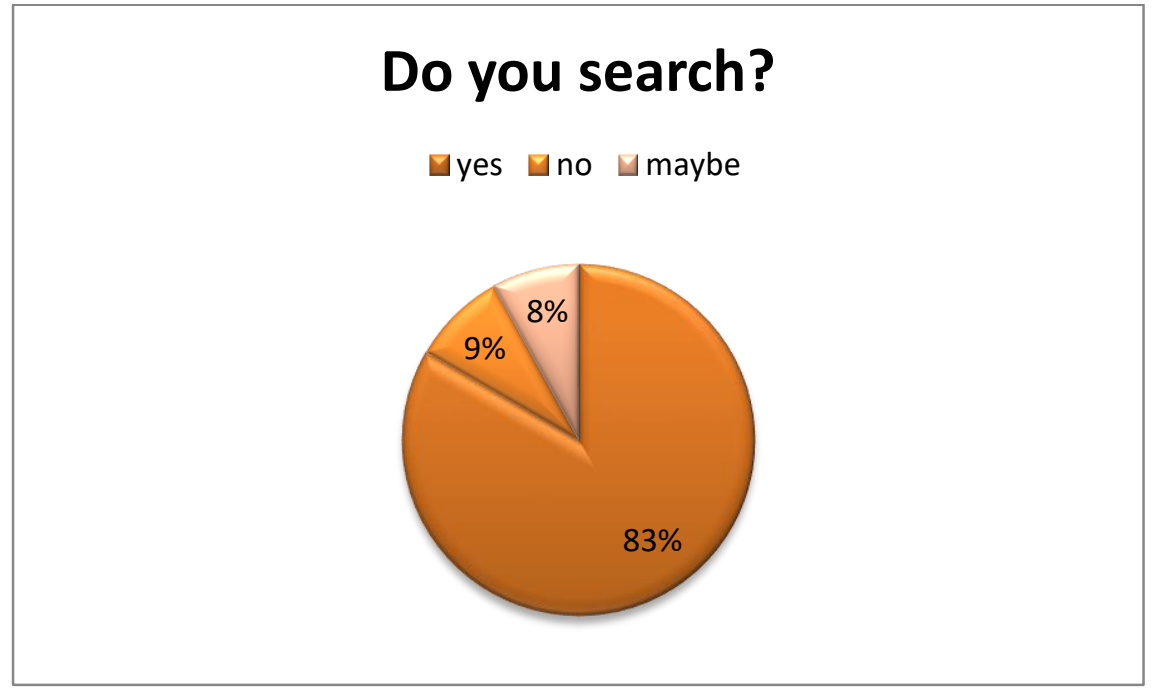

\section{Response Interpretation}

According to the above table and chart there were 125 (83\%) respondents who searched for product information before purchasing, 13 (9\%) did not search for information and $12(8 \%)$ may or may not search for have searched for information before purchase. But, argument would be whether customers check packaging and contents at first time of their purchase? Second, customers at the time of repeat purchases may not be interested in looking at packaging or details. 
2. Is it good to eat snacks in between meals?

\begin{tabular}{|ll|l|l|l|l|}
\hline & Frequency & Percent & Valid Percent & Cumulative Percent \\
\hline Valid & yes & 78 & 52.0 & 52.0 & 52.0 \\
& no & 52 & 34.7 & 34.7 & 86.7 \\
& maybe & 20 & 13.3 & 13.3 & 100.0 \\
& Total & 150 & 100.0 & 100.0 & \\
\hline
\end{tabular}

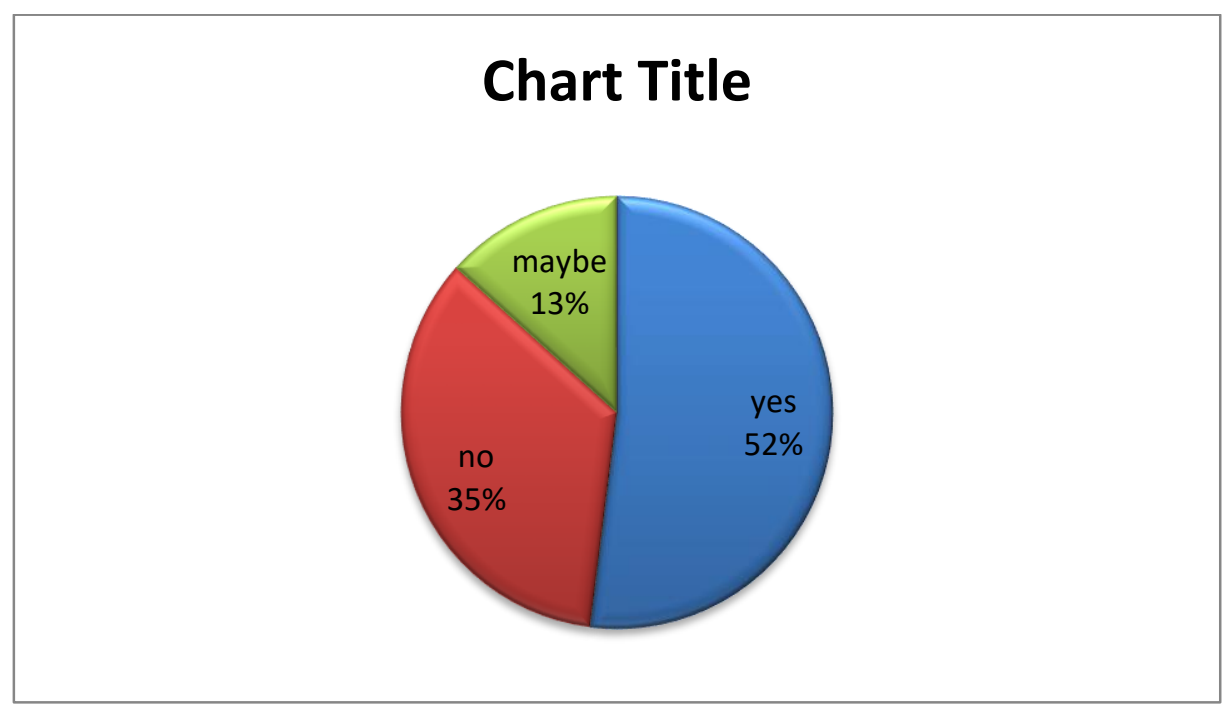

\section{Response Interpretation:}

According to the above table and chart there were 78(52\%) respondents who opined that it's nice to have snacks between meals. 52(35\%) opined that they don't prefer snacks in between meals and $20(13 \%)$ maybe they prefer sometimes.

\section{Is snacking each day healthy?}

\begin{tabular}{|ll|l|l|l|l|}
\hline & Frequency & Percent & Valid Percent & Cumulative Percent \\
\hline Valid & yes & 56 & 37.3 & 37.3 & 37.3 \\
& no & 58 & 38.7 & 38.7 & 76.0 \\
& maybe & 36 & 24.0 & 24.0 & 100.0 \\
& & 100.0 & 100.0 & \\
\hline
\end{tabular}




\section{Snacks Healthy}

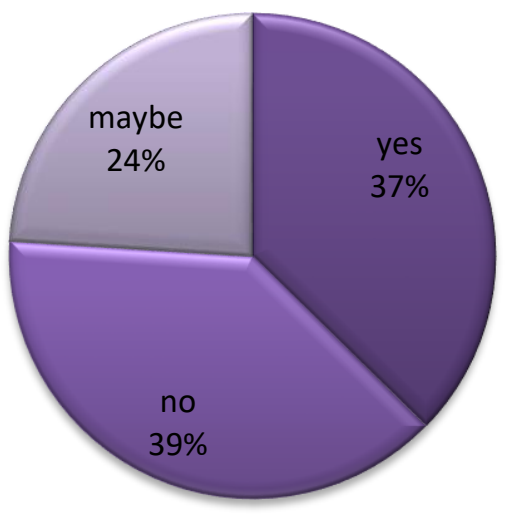

\section{Response Interpretation}

According to the above table and chart there were 58 (39\%) respondents who opined that snacking is not healthy. 56(37\%) opined that snacking is healthy and $36(24 \%)$ opined that snacking may be healthy.

\section{How many times should one snack per day?}

How many times should one snack per day?

\begin{tabular}{|c|c|c|c|c|c|}
\hline & & Frequency & Percent & Valid Percent & Cumulative Percent \\
\hline \multirow[t]{6}{*}{ Valid } & 1 & 62 & 41.3 & 41.3 & 41.3 \\
\hline & 2 & 58 & 38.7 & 38.7 & 80.0 \\
\hline & 3 & 12 & 8.0 & 8.0 & 88.0 \\
\hline & 4 & 14 & 9.3 & 9.3 & 97.3 \\
\hline & 5 & 4 & 2.7 & 2.7 & 100.0 \\
\hline & Total & 150 & 100.0 & 100.0 & \\
\hline
\end{tabular}




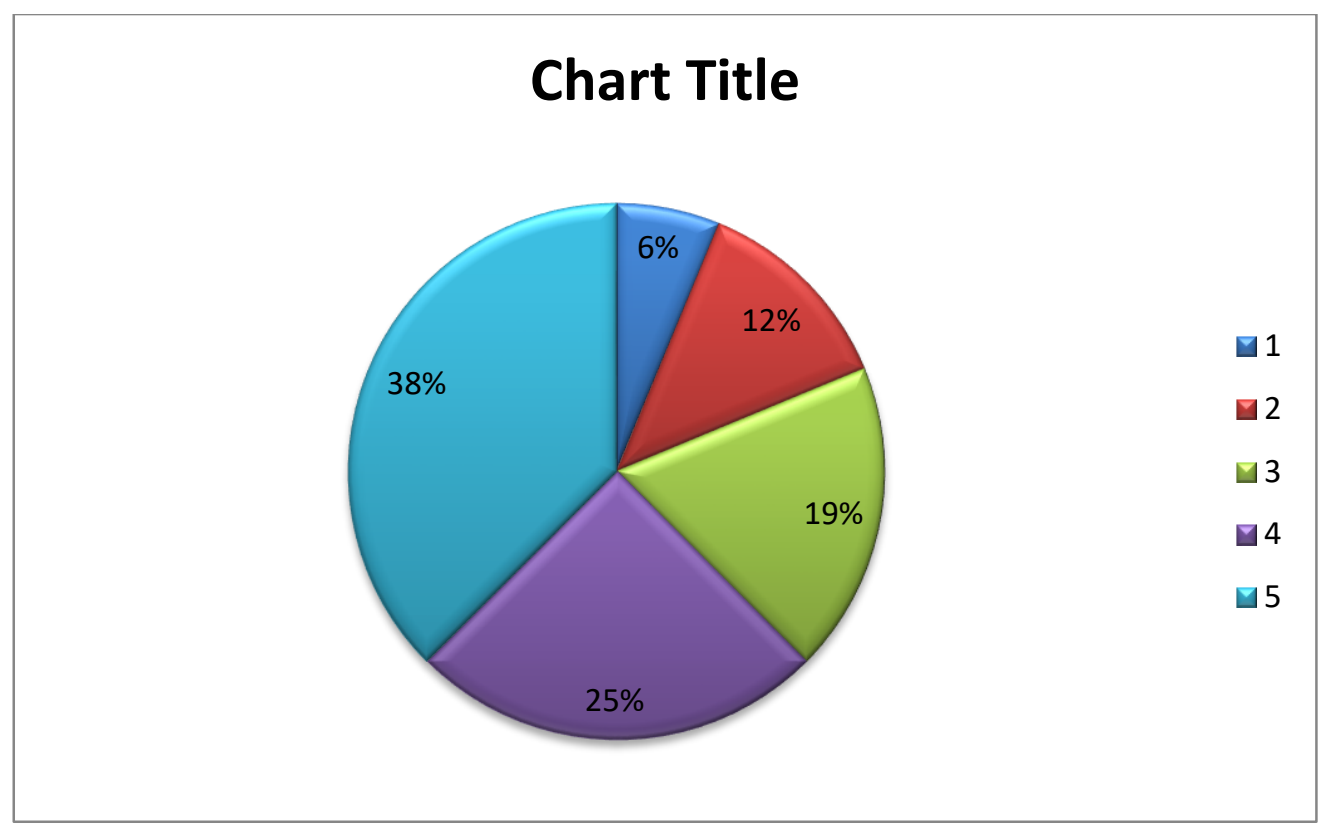

\section{Response Interpretation}

According to the above table and chart there were 62(41\%) respondents revealing that they at least buy / have snacks once a day. 58 (39\%) respondents say its ok to have twice a day. $12(8 \%)$ have 3 times a day. 14(9\%) have 4 times a day and $4(3 \%)$ say that they have 6 times a day.

\section{Where do you get your favorite Snacks?}

Where do you get your favorite Snacks?

\begin{tabular}{|ll|l|l|l|l|}
\hline & Frequency & Percent & Valid Percent & Cumulative Percent \\
\hline Valid & Super market & 49 & 32.7 & 32.7 & 32.7 \\
& & & 2.7 & 2.7 & 35.3 \\
online & 4 & 64.7 & 64.7 & 100.0 \\
Local store & 97 & 100.0 & 100.0 & \\
Total & 150 & &
\end{tabular}




\section{Where do you purchase?}

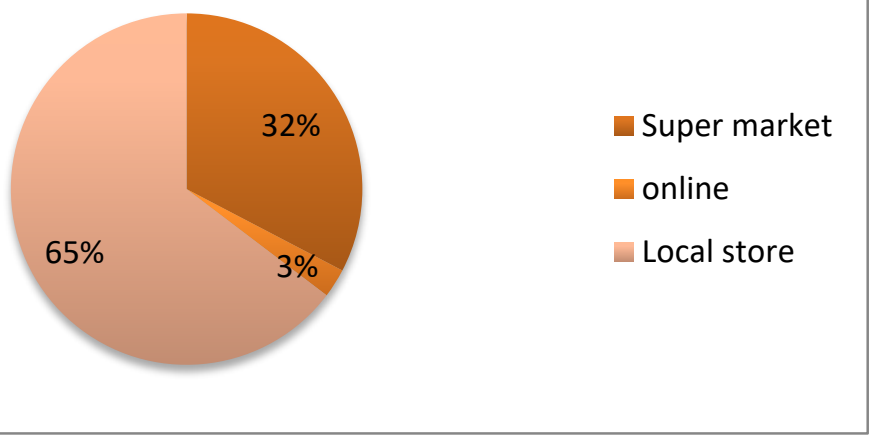

\section{Response Interpretation}

According to the above table and chart there were 97(65\%) respondents who get snacks from local stores. 49 (33\%) purchase from super market and $4(3 \%)$ purchase from online.

\section{Which of the following are important to you in a snack?}

\section{Total Variance Explained}

\begin{tabular}{|l|l|l|l|l|l|l|}
\hline \multirow{2}{*}{ Component } & \multicolumn{2}{|l|}{ Initial Eigenvalues } & \multicolumn{2}{l|}{ Extraction Sums of Squared Loadings } \\
\cline { 2 - 7 } & Total & \% of Variance & Cumulative \% & Total & \% of Variance & Cumulative \% \\
\hline 1 & 1.870 & 46.739 & 46.739 & 1.870 & 46.739 & 46.739 \\
2 & .862 & 21.544 & 68.282 & & & \\
3 & .801 & 20.028 & 88.310 & & & \\
4 & .468 & 11.690 & 100.000 & & & \\
\hline
\end{tabular}

Extraction Method: Principal Component Analysis.

\section{Component Matrix ${ }^{\mathrm{a}}$}

\begin{tabular}{|l|l|}
\hline & Component \\
\cline { 2 - 2 } & 1 \\
\hline $\begin{array}{l}\text { Which of the following are important } \\
\text { to you snack? [Taste] }\end{array}$ & .574 \\
$\begin{array}{l}\text { Which of the following are important } \\
\text { to you snack? [Nutriotional] }\end{array}$ & .728 \\
$\begin{array}{l}\text { Which of the following are important } \\
\text { to you snack? [Price] } \\
\begin{array}{l}\text { Which of the following are important } \\
\text { to you snack? [Quality] }\end{array}\end{array}$ & .573 \\
\hline
\end{tabular}

Extraction Method: Principal Component Analysis. 
Component Matrix ${ }^{a}$

\begin{tabular}{|l|l|}
\hline & Component \\
\cline { 2 - 2 } & 1 \\
\hline $\begin{array}{l}\text { Which of the following are important } \\
\text { to you snack? [Taste] }\end{array}$ & .574 \\
Which of the following are important & .728 \\
$\begin{array}{l}\text { to you snack? [Nutriotional] } \\
\text { Which of the following are important } \\
\text { to you snack? [Price] }\end{array}$ & .573 \\
$\begin{array}{l}\text { Which of the following are important } \\
\text { to you snack? [Quality] }\end{array}$ & .825 \\
\hline
\end{tabular}

Extraction Method: Principal Component Analysis.

A.1 components extracted.

Response Interpretation: According to the above table and chart shown priorities given to the first quality was 825 and this gives nutritional 728. Then customers think about taste 574 and price 573 this is the value of the snacks.

Which of the following are important to you snack? [Taste]

\begin{tabular}{|c|c|c|c|c|c|}
\hline & & Frequency & Percent & Valid Percent & Cumulative Percent \\
\hline \multirow[t]{5}{*}{ Valid } & strongly agree & 90 & 60.0 & 60.0 & 60.0 \\
\hline & agree & 44 & 29.3 & 29.3 & 89.3 \\
\hline & nutral & 14 & 9.3 & 9.3 & 98.7 \\
\hline & disgree & 2 & 1.3 & 1.3 & 100.0 \\
\hline & Total & 150 & 100.0 & 100.0 & \\
\hline
\end{tabular}




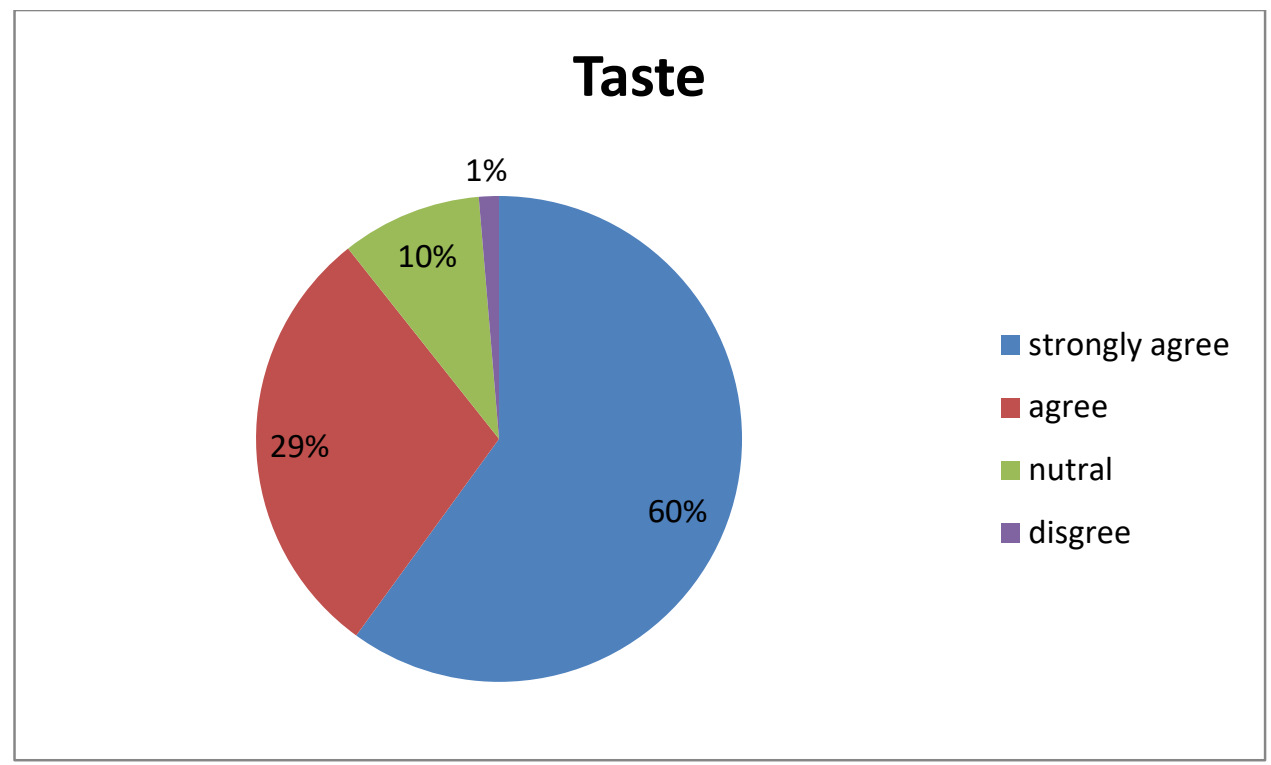

\section{Response Interpretation}

According to the above table and chart shown, $90(60 \%)$ strongly agree that taste is important in snacks, 44 (29\%) agree for taste is important, 14 (9\%) are neutral about it and 2 $(1 \%)$ disagrees that taste is important.

Which of the following are important to you snack? [Quality]

\begin{tabular}{|ll|l|l|l|l|}
\hline & & & & \\
& & Frequency & Percent & Valid Percent & Cumulative Percent \\
\hline Valid & strongly agree & 85 & 56.7 & 56.7 & 56.7 \\
& agree & 29.3 & 29.3 & 86.0 \\
& nutral & 20 & 13.3 & 13.3 & 99.3 \\
disgree & 1 & .7 & .7 & 100.0 \\
Total & 150 & 100.0 & 100.0 & \\
\hline
\end{tabular}




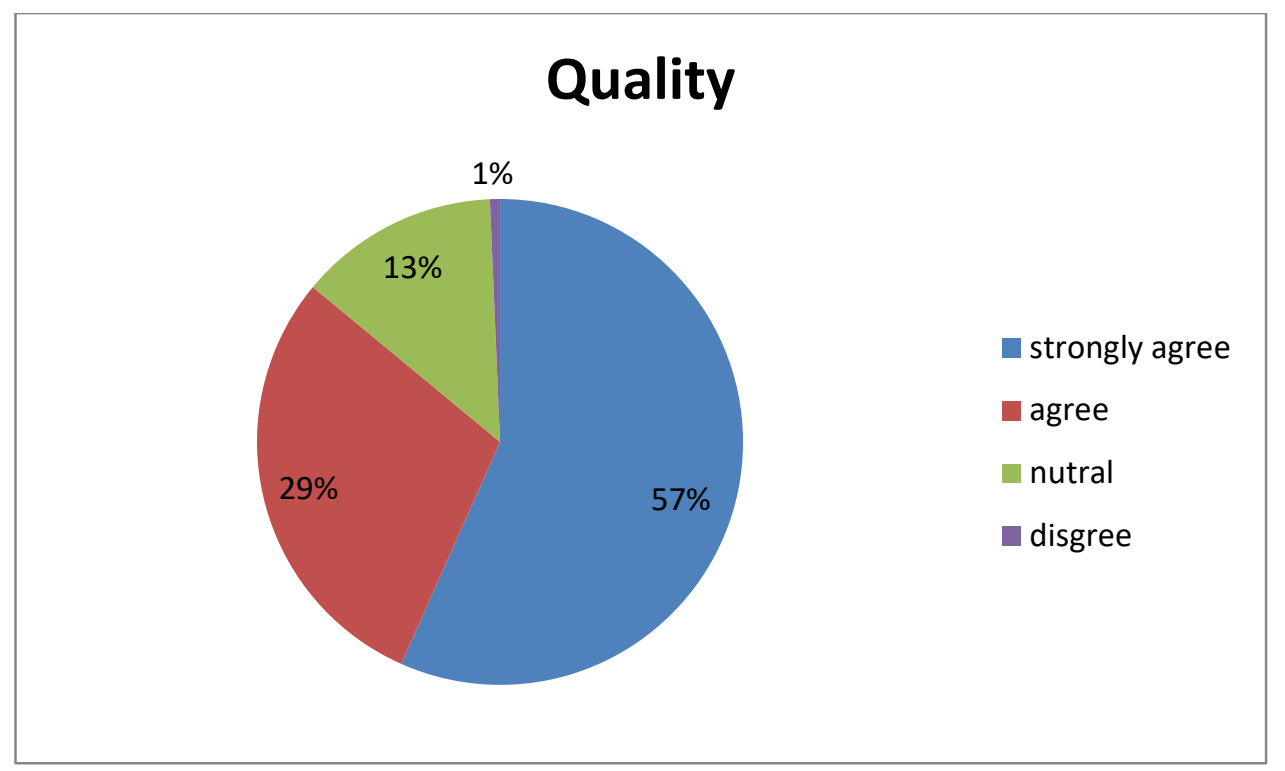

\section{Responsive Interpretation}

According to the above table and chart shown, 85(57\%) strongly agree that Quality is important in snacks, 44 (29\%) agrees for quality is important. 20(13\%) are neutral about it and $1(1 \%)$ disagree that quality is important

Which of the following are important to you snack? [Price]

\begin{tabular}{|ll|l|l|l|l|}
\hline & & & & \\
& & Frequency & Percent & Valid Percent & Cumulative Percent \\
\hline Valid & strongly agree & 49 & 32.7 & 32.7 & 32.7 \\
& agree & 54 & 36.0 & 36.0 & 68.7 \\
& nutral & 44 & 29.3 & 29.3 & 98.0 \\
strongly disagree & 1 & .7 & .7 & 98.7 \\
disgree & 2 & 1.3 & 1.3 & 100.0 \\
Total & 150 & 100.0 & 100.0 & \\
\hline
\end{tabular}




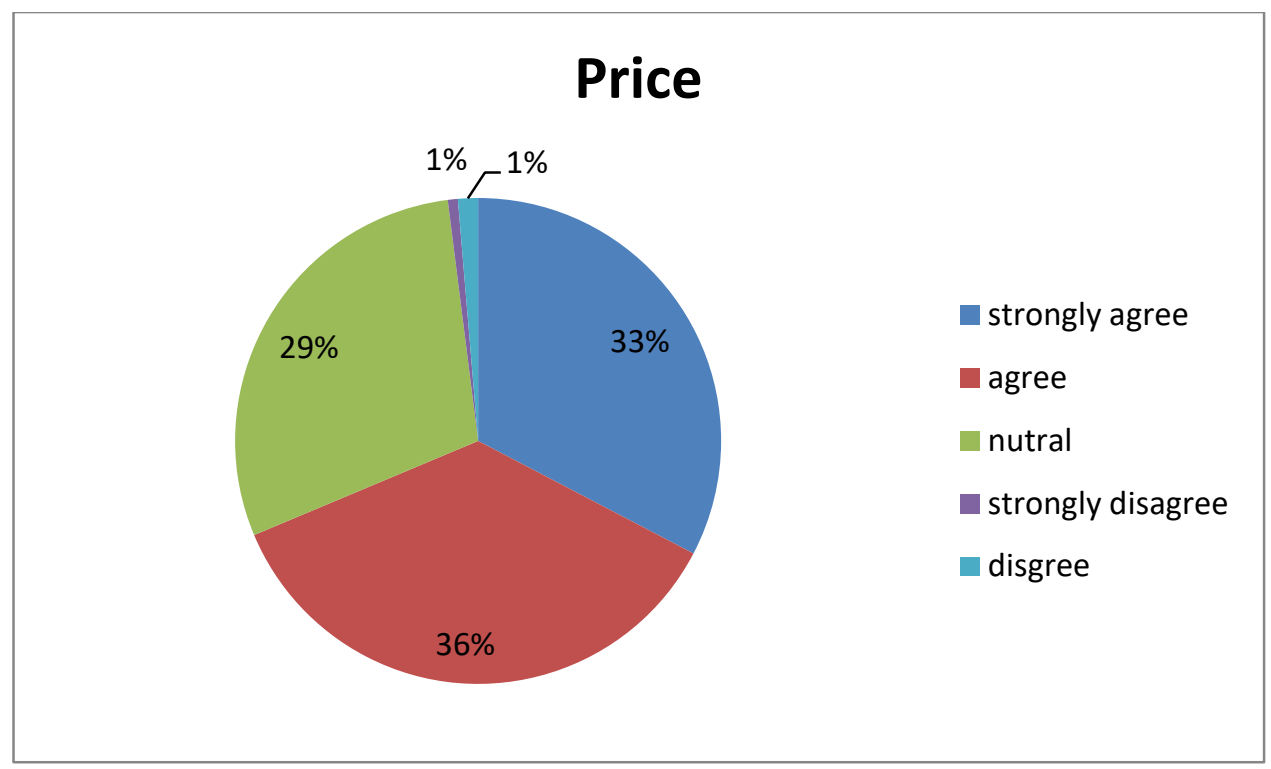

\section{Response Interpretation}

According to the above table and chart there were 49 (33\%) who strongly agree for price as important for snacks. 54(36\%) agree that price is important in snacks. $44(29 \%)$ are neutral about it. $01(1 \%)$ strongly disagrees to it and $2(1 \%)$ disagree that price is important.

Which of the following are important to you snack? [Nutriotional]

\begin{tabular}{|ll|l|l|l|l|}
\hline & Frequency & Percent & Valid Percent & Cumulative Percent \\
\hline Valid & strongly agree & 60 & 40.0 & 40.0 & 40.0 \\
agree & 56 & 37.3 & 37.3 & 77.3 \\
Neutral & 28 & 18.7 & 18.7 & 96.0 \\
strongly disagree & 2 & 1.3 & 1.3 & 97.3 \\
disagree & 4 & 2.7 & 2.7 & 100.0 \\
Total & 150 & 100.0 & 100.0 & \\
\hline
\end{tabular}




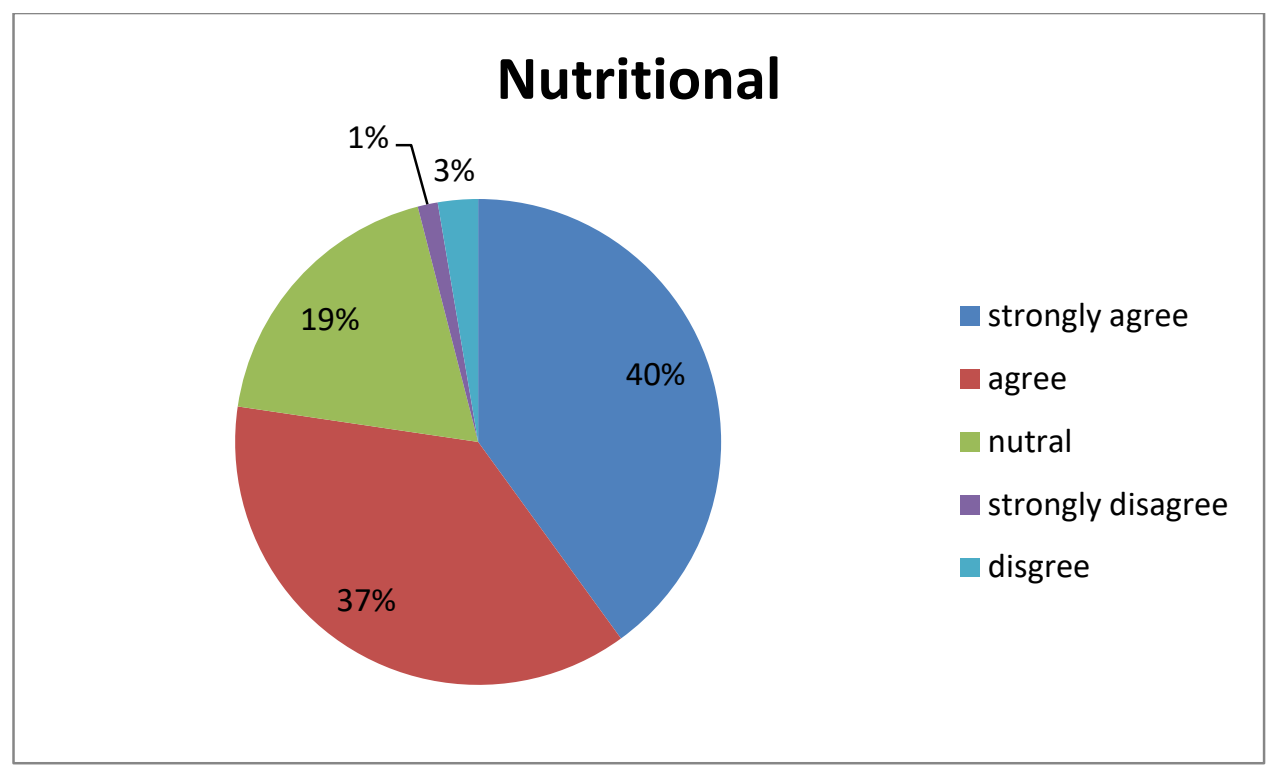

\section{Response Interpretation}

According to the above table and chart there were $60(40 \%)$ who strongly agree that nutriotion is important in snacks. 56(37\%) agree for nutrition is important. 28(19\%) are neutral about it. $02(1 \%)$ strongly disagrees to it and $4(3 \%)$ disagrees that nutrition is important

\section{How much money do you spend in a day for Snacks}

How much money should one spend on snacks?

\begin{tabular}{|ll|l|l|l|l|}
\hline & & Frequency & Percent & Valid Percent & Cumulative Percent \\
\hline Valid & $10-20$ & 57 & 38.0 & 38.0 & 38.0 \\
& $20-40$ & 51 & 34.0 & 34.0 & 72.0 \\
$40-60$ & 18 & 12.0 & 12.0 & 84.0 \\
60 above & 24 & 16.0 & 16.0 & 100.0 \\
Total & 150 & 100.0 & 100.0 & \\
\hline
\end{tabular}

\section{Response Interpretation:}

According to the above table $57(38 \%)$ spend $10-20$ on snacks, $51(34 \%)$ spend at least 20 $40,18(12 \%)$ spends $40-60$ and last 24 (16\%) spend above 60Rs. 


\section{Which of these snacks you prefer most?}

Which snack you most preferred.

\begin{tabular}{|c|c|c|c|c|c|}
\hline & & Frequency & Percent & Valid Percent & Cumulative Percent \\
\hline \multirow[t]{8}{*}{ Valid } & chips & 77 & 51.3 & 51.3 & 51.3 \\
\hline & sweets & 16 & 10.7 & 10.7 & 62.0 \\
\hline & Biscuits & 29 & 19.3 & 19.3 & 81.3 \\
\hline & chocolates & 19 & 12.7 & 12.7 & 94.0 \\
\hline & other & 7 & 4.7 & 4.7 & 98.7 \\
\hline & Crips & 1 & .7 & .7 & 99.3 \\
\hline & Vada pav & 1 & .7 & .7 & 100.0 \\
\hline & Total & 150 & 100.0 & 100.0 & \\
\hline
\end{tabular}

\section{Which snack you prefer}

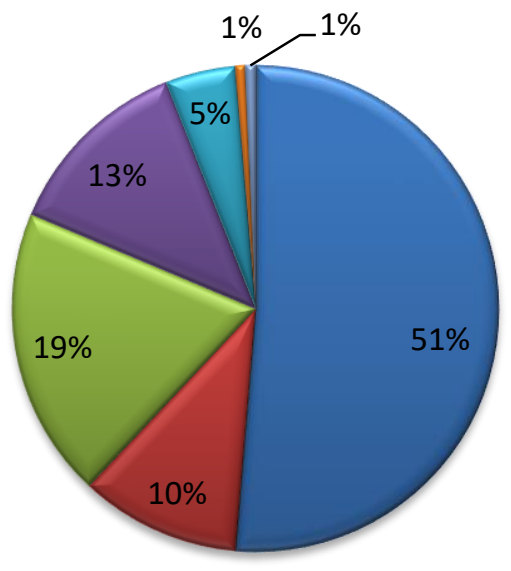

$\nabla$ chips

sweets

$\square$ Biscuits

$\nabla$ chocolates

Dother

$\square$ Crips

$\square$ Vada pav

\section{Response Interpretation}

According to the above table and chart, 77(51\%) respondents prefer chips, 29 (19\%) prefer biscuits, 19 (13\%) prefer chocolates, $16(11 \%)$ prefer sweets and $09(07 \%)$ prefer other snacks. 


\section{Tick the following option which related to most you.}

Tick the following option which related to most you

\begin{tabular}{|l|l|l|l|l|}
\hline & Frequency & Percent & $\begin{array}{c}\text { Valid } \\
\text { Percent }\end{array}$ & Cumulative Percent \\
\hline $\begin{array}{l}\text { Valid } \begin{array}{l}\text { I always Buy the same } \\
\text { brand }\end{array} \\
\begin{array}{l}\text { Sometimes i choose the } \\
\text { same brand }\end{array}\end{array}$ & 62 & 41.3 & 41.3 & 41.3 \\
$\begin{array}{l}\text { All brands are similar to } \\
\text { me }\end{array}$ & 26 & 41.3 & 41.3 & 82.7 \\
Total & 150 & 100.0 & 100.0 & 100.0 \\
\hline
\end{tabular}

\section{Response Interpretation}

According to the above table and chart 62(41\%) respondents always buys the same brand, $62(41 \%)$ choose the same brand, and 26(17\%) says that all brands are similar. 


\section{Findings and Discussion}

1) As per the study, majority of respondents opine that they would check for product information before purchase at first purchase.

2) According to the study, respondents are having a mixed reaction about snacking being healthy or not.

3) Priority while buying snacks is given to first quality, nutritional, taste and then price in the respective order.

4) As per the study, most popular snack is chips followed by biscuits, chocolates and finally sweets.

5) Customers are observed to have minimal brand choices in snacks category.

6) Respondents have articulated perception about snack brands.

7) Customers pick available brands only

8) Customers perceive willingness to snack between meals.

9) Respondent snack of 4 times per day.

10) There is lot of potential for the snacks market.

11) As per the study, local store has potential to attract $65 \%$ of customers towards snacks purchase

12) Super market potential attracts $32 \%$ of customers towards snacks purchase.

13) Majority of customers like to spend Rs 10 - Rs 40 for snacks per day.

\section{Suggestion}

1) Most respondents would like to purchase snacks in local store

2) So, manufacturer should concentrate making available of products regularly in local store. Apart from this, the companies should concentrate on super market and online sales. By providing attractive offers. Most of Manufacturer should give more preference to the tastier products and quality products

3) As per the study, customers have a dilemma that snacks are not healthy. So, manufacturer should create awareness that snacks are more nutritional and healthier through advertisement.

4) Customers don't think at all while spending on snacks worth Rs 05- V10. So, marketers must concentrate on pushing the said products with maximum availability.

5) Since customers don't recall brands much and don't seem to understand snack brand, it is easy for competitors to emulate packaging, thus invading the marketing share of original brands. Hence the brands must be careful about duplication

6) There is a scope for healthy snacks.

7) Snacks should be positioned so as to be added to regular meal or be a healthy substitute

8) Sub-packing can be done as customers perceive snacking to be done more than 04 times a day 


\section{Conclusion}

A demographical erudition in this research revealed that most of the male customers are prefer to snacks. The young adult customers are they would like to purchase the snack items. A snack eaten shortly before going to bed or during the night may be called a bedtime snack, late night snack, or mid-night snack. There is a rise in demand of snacks market which drives manufactures to grow and operate in this segment. The results indicated the total of four factors, which were analyzed quality, price, flavor, availability. The food product in market in India is becoming more important and competitive to the presence of Indian companies.

In this research most of the customers would like to purchase the snacks they are ready to eat snacks and they ready to spend money on snacks student eat snacks. Some of the regular customers are also there in market they eat snacks compared to other foods or meals.

To purchase snacks, customers prefer more for local stores because of easy availability while compare to super market and online.

In this research after analyzing the respondents it is inferred that when customer is buying the products, they should search for the product almost customer prefer same brand products. In snack, customers they like the snack taste, flavor, quality of product and also quantity when Customers likes the products, they buy the same product of brand.

A snack is the healthy and nutritional product it has high potential. The customer most prefers healthy snacks like dry fruits most of the customers are eaten the snacks between meals some of the eat after the meals. Almost the customers prefer the local stores they purchase snacks in the local store. In this research the customers spend money on snacks Rs 05 to Rs 20 per day and the most of the customers prefer the small packs because it is easy to carry. In the market most of the customers would like to prefer the chips in the industry chips has the highest sales huge income from chips and potato chips also have the demand in the market.

\section{References}

- Abdourrahmane, M. (2014). An International customer's Perception and attitude towards the purchase intentions of snack food products. Tni journal of business administration and languages.

- $\quad$ Adrim j Cameron, w. E. (2013). Does the availability of snack foods in supermarkets vary internationally. International journal of behavioral nutrition and physical activity.

- $\quad$ Anuvat Jangchud, R. A. (2019). Customer perception of extruded snacks containing brown rice and dried mushroom. . International journal of food science and technology.

- $\quad$ Duarte, P., Raposo, M., and Ferraz, M. (2013). Drivers of snack foods impulse buying economic behaviour among young customers. Emerald Group Publishing Limited. 
- $\quad$ Durate paulo, F. M. (2013). Drivers of snack foods impulse buying behavior among customers. Emerald group Publishing limited.

- Emily C, C. A. (2013). Customers expectations and needs towards healthy cereal based snacks. British food journal.

- Kulkarni, M. S. (1791). Snacks Buying behavior in a pack priced at Rs 5/- . International Journal of multidisciplinary Research.

- Mr.Rajiv Vyas, D. S. (2016). A Study on Customer Behavior towards Food snack Items of Popular Brands. IOSR Journal of business and management.

- $\quad$ Peter Hannam, R. W. (1997). A Pricing strategy to promote low-fat snack choices through vending machines. American journal of public health.

- R. Vijaylaxmi, L. G. (2020). Customer-Buying-Economic behaviour-TowardsSnacks-Food-Products.

\section{Bibliography}

- Abdourrahmane, M. (2014). An International customer's Perception and attitude towards the purchase intentions of snack food products. Tni journal of business administration and languages.

- $\quad$ Adrim j Cameron, w. E. (2013). Does the availability of snack foods in supermarkets vary internationally. International journal of behavioral nutrition and physical activity.

- $\quad$ Anuvat Jangchud, R. A. (2019). Customer perception of extruded snacks containing brown rice and dried mushroom. . International journal of food science and technology.

- $\quad$ Duarte, P., Raposo, M., and Ferraz, M. (2013). Drivers of snack foods impulse buying economic behaviour among young customers. Emerald Group Publishing Limited.

- $\quad$ Durate paulo, F. M. (2013). Drivers of snack foods impulse buying behavior among customers. Emerald group Publishing limited.

- $\quad$ Emily C, C. A. (2013). Customers expectations and needs towards healthy cereal based snacks. British food journal.

- Kulkarni, M. S. (1791). Snacks Buying behavior in a pack priced at Rs 5/- . International Journal of multidisciplinary Research.

- Mr.Rajiv Vyas, D. S. (2016). A Study on Customer Behavior towards Food snack Items of Popular Brands. IOSR Journal of business and management.

- $\quad$ Peter Hannam, R. W. (1997). A Pricing strategy to promote low-fat snack choices through vending machines. American journal of public health.

- R. Vijaylaxmi, L. G. (2020). Customer-Buying-Economic behaviour-TowardsSnacks-Food-Products. 